(c) EUSP, $2017 \quad$ ej ISSN 2310-3817 Vol.5 SÍCSIS No.2 (engl) p. 266-288

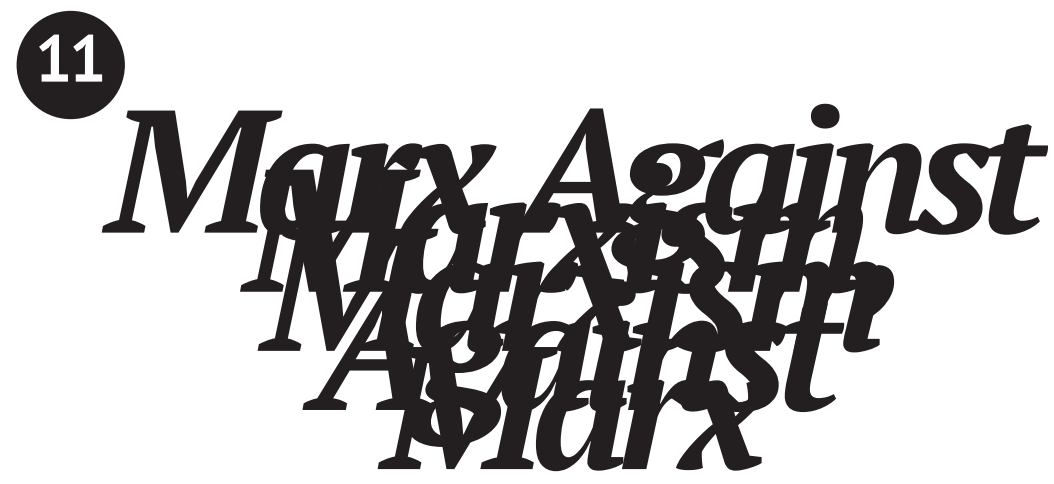

\title{
Marx Against Marxism, Marxism Against Marx
}

[A Talk with Valery Podoroga on Soviet Philosophy]

Keti Chukhrov (Research University Higher School of Economy, Department of the Humanities, Moscow), Alexei Penzin (University of Wolverhampton and the Institute of Philosophy, Moscow), Valery Podoroga (Institute of Philosophy, Russian Academy of Sciences)

\section{Soviet Marxism or Soviet Marxisms?}

Keti Chukrov: I'm truly curious about the philosophical status of Soviet Marxism in the context of Western Marxism. There are figures whom it's difficult to imagine being integrated into contemporary critical thought or, especially, aesthetic theory. Nonetheless, the aesthetics of Lukács, though just barely, have made it into the corpus of modern aesthetics and epistemology, while the works of Ilyenkov, let alone Lifshitz, have not. These names are dogged by a certain marginality. In addition, the reading of Marx itself has led to extremely varied results in the Soviet and Western contexts respectively. For example, Ilyenkov distilled from Marx the very categories and concepts for which Western thought of that time found no use: the ideal, the universal, labor as a form of culture, and so on. Althusserian critical Marxism locates such categories within the early, humanist Marx. In effect, the range of models of social purpose that emanate from one source can be quite varied. 
Valery Podoroga: You are right that Western Marxism and its fundamental ideas were formed outside of the influence of the most important representatives of what we call Soviet Marxism. Although, individual works by Evald Ilyenkov and Lev Vygotsky were translated by Progress Publishers and became fairly well known, for example among American and British Marxists. But, of course, being cut off for many years from participation in the cultural and political processes taking place in the West had the effect of making our most advanced thought close in on itself, in its solitude, in the constant neurosis of waiting for new Party purges and repressions. Western ("Left”) Marxism has its own rich history, which, even if it was once connected with Eastern Marxism-Leninism, was so only in the sphere of cooperation among various Communist Parties. Our best minds of the 1960s could not take their eyes away from that dismal and distorting mirror of "actually existing socialism." They hoped that suddenly we would get lucky and find ourselves beyond that looking glass...

Alexei Penzin: My questions relate to your recent lecture on Mikhail Lifshitz (Podoroga 2016). If I'm not mistaken, you distinguished four types of Soviet Marxism: Hegelian Marxism (primarily Evald Ilyenkov), nomenclatural-dogmatic (within the framework of the Soviet "ideological apparatus”), scientific Marxism, and “leftist” Marxism. I don’t fully understand the last type; whom would it include?

Valery Podoroga: I will risk taking up your time with an exhaustive answer. I will start with listing the different "Marxisms." In the USSR at that time the most widespread form of "Marxism" was "Marxism-Leninism," or the Party-nomenklatura, dogmatic form of ideology, serving as the window dressing or decoration for the one-party CPSU system. Into that we should include teaching practices in higher education, which were entirely defined by dialectical materialism, historical materialism, scientific communism, and the history of the CPSU, purely Party-line ideological disciplines. They, incidentally, were required for students in higher education.

1. In terms of theory, Left Marxism does not represent anything interesting or new. And, of course, it had nothing whatsoever to do with the pro-communist positions in theory that were taken by Karl Korsch and Georg Lukács. Having been formed within the Party-state nomenklatura system, it was the ideological-representative superstructure of that system. If you like, each "leftist" in the nomenklatura wanted to be more Catholic than the Pope. I learned from Sergei Zemlyanoi, at one time part of the group of speechwriters for CPSU Central Committee General Secretary Yuri Andropov and later his successor Konstantin Chernenko, how the upper strata at that time existed ideationally-ideologically and politically. The "left" group consisted of relatively young people, energetic and extremely ambitious, oriented toward a big career in the Party. They were 
mostly graduates of the Komsomol (first secretaries of different types of Komsomol organizations). This group was quite influential and was opposed to another, similar one, with a different orientation, and was close to the broad humanitarian opposition to the regime (all those who had their "tongue in cheek")-the liberal-nomenklatura Fronde, fairly cynical, well-educated, inclined toward managed reforms of the country's Party leadership.

2. Dialectical, Hegelian Marxism was represented above all by Evald Vasilyevich Ilyenkov, as well as younger colleagues who were close to him, among whom we must name Genrikh Batishchev and Viktor Vaziulin. The dialectical method was seen as a precondition of the development of new Marxist science, which should be constructed based on a single modelMarx's Capital. Not only did it have to simply present the ideal model for the organization of knowledge, but it had to become the universal science-the science of sciences.

3. The strongest revitalizing influence on Marxist doctrine was exerted by the existentialist movement that arose after the Second World War (Sartre, Heidegger, Jaspers, Enzo Paci, Ortega y Gasset, and many others). We could also add studies of Marx's early works to that group, and the discovery of the humanist image of Marx and shift in individual countries of the Eastern bloc toward the doctrine of "socialism with a human face." ${ }^{1}$ The Prague Spring of 1968 was intellectually prepared as an existential revolution, oriented toward humanist renewal, "humanizing" the socialism of old Marxist-Leninist dogmas. It is true that toward the end of the sixties the critique of the existential-humanist interpretation of Marxism gained momentum in the West (probably as a result of the failure of the reform process of the Czechoslovakian political regime). ${ }^{2}$ At that point the earlier formula, positing an optimistic exploratory horizon, "Marxism is a humanism," began to be viewed as false and Utopian.

4. Next there is scientific-structural Marxism, with which I was primarily involved. It included the outstanding orators, true leaders of underground critical thought, scholars and philosophers: Aleksander Zinoviev (2002), Georgy Shchedrovitsky (2004, see also Khromchenko 2004), Boris Grushin (1961), and Merab Mamardashvili (1968). In parallel with that tendency, a kindred group of thinkers in France, led by Louis Althusser (Étienne Balibar, Jacques Rancière, and others), proclaimed the theme of "scientific Marx" that was to revitalize dogmatic Marxism. The Moscow and Paris circles of Marxian philosophers resonated with each other in some ways, and learned from each other (for example, Louis Althusser

To this we should add some works published in the sixties by Iurii Zamoshkin, Nelly Motroshilova, Erikh Solovyov, Piama Gaidenko, Iurii Davydov, Iurii Borodai.

2 The military invasion of Czechoslovakia by the Warsaw Pact countries in August 1968, which led to a crackdown on the broad civic opposition, who were demanding radical change from the pro-Soviet political regime. 
and Merab Mamardashvili became friends [Mamardashvili 2016]). The critique of existential humanism of the Sartrean type began to grow in connection with the strengthening position of structuralism and the introduction into the human sciences of new linguistic and semiotic methods in France (Lévi-Strauss, Althusser, Foucault, and many others).

Alexei Penzin: You have also voiced a rather provocative thesis, that in this way, "Soviet Marxism," as such, in the singular, did not exist. After all, according to your hypothesis, it consisted-in the late Soviet period, at least-of several different formations, of which it is apparently impossible to distinguish one "main," basic one. Such an analysis, which underscores the multiplicity of discourses and the richness of the individual variations contained in that multiplicity, is unquestionably of critical importance, insofar as it disrupts the image of a kind of dogmatic monolithic aspect which has insistently been imposed on these forms of Marxist thought. Though it would be interesting, also, to reflect upon what constituted the specificity and the contemporary relevance of Soviet thought as a whole. That question, in fact, is what this entire issue of our journal is attempting to answer. At the same time, to the extent that I understand the thesis of your lecture, the only "authentic" Marxism was the Marxism of Mikhail Lifshitz, which gives him a particular and symptomatic position in the landscape we are discussing. Lifshitz returns to the model of Marxism as a "ruthless critique" of all revisionist positions, but it seems that he does not offer any "positive" theoretical model.

Valery Podoroga: What does it mean that Lifshitz doesn't offer any positive model? One already exists - the model of orthodox Marxism. Earlier on I had, one might say, no connection with Lifshitz, given that my generation did not consider that language, or those ideas, or all that old "Marxism-Leninism" something important and necessary for understanding the contemporary world. In fact we studied Marx, but it was rather from a post-Marxist perspective than from Lenin's perspective. We knew enough about Lenin's works to pass our exams on the history of the CPSU, while Marx we actually studied in some depth, but not as the social revolutionary and author of The German Ideology, rather as a European thinker who put forward (with the help of Hegel) important ideas in the domain of understanding the nature of consciousness and the forms of its functioning. As we continually compared our experience of reading Marx with European thinkers and the most important "post-Marxists" (Althusser, Adorno, Lukács), we felt that we were in touch with what was going on in the world. The works of such philosophers as Aleksander Zinoviev, Vladimir Bibler, Merab Mamardashvili, Evald Ilyenkov, and Borish Grushin played an important part in this process. The general slogan was "Back to Marx": to the real Marx, the scientific one, Marx the thinker! Down with Marxist-Leninist ideology, that was false consciousness, which, 
from the sixties on, was revealed to be completely exhausted, empty, having abandoned the belief in world revolution, belief in the possibility of building an ideal society of free people, a society of social justice!

What was peculiar to Lifshitz's position among “Soviet Marxisms” was that he reckoned himself an adherent of what was known as the "Left-Communist Marxism" of the thirties (the pre-Stalinist period). His credo was: the critique of all kinds of "ideas," "idealisms," and "vestiges" of bourgeois society must be immoderate and ruthless, Leninist, or not exist at all. And that means that it should be based on the ideas and values of an ideal social order, unattainable in the present reality or in any foreseeable future. Such a society presents itself in the form of the Kantian thing-in-itself-as a regulating idea. Later on, "post-Marxism" would move in the same direction. Among those who knew this and "had a good feeling for" the critical direction of Marxism, I would name Ernst Bloch with his philosophy of hope, Walter Benjamin with the dialectical image, Theodor Adorno and negative dialectics, Herbert Marcuse with the new sensibility-a group of philosophers and theoreticians close to the Frankfurt School at the Institute for Social Research. And, of course, Sartre and existentialism/humanism. The slogans of the 1968 student revolution in Paris are purely Sartrean: "Demand the Impossible!", "All Power to the Imagination!" and so on.

Lifshitz appropriates fashionable "leftism," proclaiming himself an orthodox Marxist, underscoring his old, close ties with Lukács and Left Communists of the thirties. Orthodox Marxism is that minimum core of fundamental positions of Marxism which cannot be denied, "improved upon," or betrayed: they are established once and for all. Here I will quote an important passage:

Even if [recent research had disproved every one of Marx's theses], every serious "orthodox" Marxist would still be able to accept all such modern findings without reservation and hence dismiss all of Marx's theses in their entirety-without having to renounce his orthodoxy for a single moment. Orthodox Marxism, therefore, does not imply the uncritical acceptance of the results of Marx's investigations. It is not the "belief" in this or that thesis, nor the exegesis of a "sacred" book. On the contrary, orthodoxy refers exclusively to method. It is the scientific conviction that dialectical materialism is the road to truth and that its methods can be developed, expanded and deepened only along the lines laid down by its founders. It is the conviction, moreover, that all attempts to surpass or "improve" it have led and must lead to over-simplification, triviality and eclecticism (Lukács 1971: 1).

The victims of Lifshitz's critical interrogations were taken by surprise in that it was he who made the choice, he who chose them, not they who chose him. And that makes sense, insofar as he acts in the name of 
integrity and "clearing the ranks" and on behalf of the knowledge of authentic science, of Truth itself. I will just note, however, that taking a critical stance toward whatever material is at hand is completely natural for any literary critic. But Lifshitz was not just a critic, he was a critic who based his arguments on the principles of orthodox Marxism, and his main purpose was to completely unmask his ideological opponents.

Alexei Penzin: Thank you for that fully developed answer. I would like to clarify that in standard history of philosophy classifications, the term "post-Marxists" is used to refer to a later generation (the students of Lukács and Althusser, in fact-Ágnes Heller, Jacques Rancière, Alain Badiou, Étienne Balibar, and others) [...] Then again, I'm aware that such classifications are to a significant degree conditional, and your remark that a certain group of critical Soviet intellectuals read Marx "in a postMarxist perspective"-prior to the emergence of such a reading in the "Western" context-seems highly important. I think that the following hypothesis would be interesting: Lifshitz, with his Marxist orthodoxy, with all the immoderation and ruthlessness of his demands, without even suspecting as much, from today's perspective looks, paradoxically, like a "post-Marxist" [...] I mean that Lifshitz, if I may be permitted a joke, in a sense, "demanded the impossible" from Brezhnev! Also, you said that you used to feel differently about Lifshitz. In what way has your position evolved since then?

Valery Podoroga: Earlier, as I said, I had no interest in Lifshitz as a philosopher. But then I was given a whole series of Mikhail Lifshitz's posthumously published work and began to read it [...] Naturally, I began to take a profound interest in it, but at that point it was still in terms of reminiscence and biography-thinking about my own Soviet past. Thought exists in time, and can never cut across the boundaries designated for it by the period. And that was immediately noticeable, as soon as I began carefully reading the Marxist master's texts: not the same problems, the questions, desires, the hopes are all different and don't fit. None of it fits with my experience today or my theoretical orientations (leaving aside political orientations).

\section{2. “Doublethink" and Late Soviet Philosophy}

Alexei Penzin: What events or processes, in your view, represent the most important external conditions of the development of Marxist philosophy in the society of the late Soviet period?

Valery Podoroga: After a certain point, “doublethink” became a generally accepted solution at all layers of society. It cannot be said not to 
have existed before, but it was only in 1972, when consultations began in preparation for the Conference on Security and Cooperation in Europe (the treaty was finally approved in 1975), that this doublethink received the backing of the state and became widely disseminated. What did it consist of? The fact that you can discuss serious problems of everyday life, and do so not only in the kitchen, or you can pretend that you are working for "that amount of money," but you must not touch on political themes or the authorities. Since the government had a need for a fairly large group of specialist consultants for joint projects with the West, it found itself having to close its eyes to certain ideational or ideological inconsistencies. The main thing was for words of protest and criticism not to be reflected or carry anti-Soviet resonance in the public sphere, but you could study whatever interested you as long as you keep up appearances, and avoid sticking your neck out or provoking the authorities. It was possible to get around all the formal rules, but again, you had to observe this pact with the authorities, an unsigned, but effective pact. The dissident movement did a great deal to destroy this "double" morality, this "doublethink," but did not take into account (or did not want to take into account) this collusion between society and the government.

In the late sixties the building of the Institute of Scientific Information for Social Sciences (INION) of the Russian Academy of Sciences was constructed, and in the early seventies its holdings began to grow, restricted-access collections were opened with quite extensive access to Western periodicals. At that point there took place a wide-ranging institutionalization of this political doublethink, undermining the foundations of Communist ideology. The culminating stage was: one truth, the truth of "inner freedom"-for intellectuals, whose hunger for information is now fully appeased, but they must keep silent; the other-for the proletarian masses, the workers and peasants. INION at this new stage of government ambiguity and doublethink had to prepare reports, references, and annotations for the Party apparatus, that is, had to be an instrumental institutional intellectual body for higher Party circles. Every section of INION had its own task and specialization. Restricted-access collections opened; doctoral students and young research associates began to be allowed access to them. For me-a doctoral student at the Russian Academy of Sciences' Institute of Philosophy-permission to use the restricted-access collections was a real eye-opener. The world expanded a lot, and we began to know a great deal more about the world. And young research associates of the Academy's human sciences institutes earned good money with their reports.

An unbelievable torrent of information began flowing in from the West. At our institute, a periodicals section opened-it would be unthinkable now, but it's also unnecessary-and all of the most important philosophy and social science journals from many European countries arrived there, as well as dictionaries and reference materials. For the community of humanists (students, graduate students, young teachers) 
knowledge became a drug, we were dumbfounded by its availability and variety. It's hard to imagine the kind of heroes of knowledge we had in our studies. An extremely modest life, at the library from morning until evening. Year after year. The most popular and extensive library holdings were at the Lenin Library, the History Library, and the Library of Foreign Literature, and, of course, at the Gorky Library at Moscow State University, the one on Mokhovaya Street next to the journalism faculty. Both the dissident movement and, in general, free thinking were in many ways defined by society's growing level of informedness. Freedom coincided with your desire to keep knowing more. As a participant in this feast of knowledge, this incredible cult of the intelligent and necessary book, I think that everything that belongs to my generation that has meaning or value came about precisely due to this explosion of information.

Here's one more example of institutionalized (state) doublethink, in which I also participated as a future $\mathrm{PhD}$ candidate. In the seventies, GlavLit (the Main Administration for Safeguarding State Secrets in the Press) was allotted its own peculiar genre of scholarly work: "DSP" (Dlya Sluzhebnogo Polzovaniya, or For Restricted Use). After being published in those scholarly collections you could defend (presenting your dissertation at the State Commission for Academic Degrees and Titles). I published part of my thesis on Adorno's "negative dialectics" in the journal Voprosy filosofii (Problems of philosophy)(I remember the section editor Armen Arzakanian with much gratitude), and the other part in a collection of DSP materials. Both very bad and very good scholars took advantage of those opportunities to the fullest extent. DSP materials were published in limited circulation, practically without any kind of editorial or publishing preparation, and without "attentive" censorship as well. And aside from specialists, nobody knew anything about them; such publications were marginal, pure hybrid creations of Soviet scholarly doublethink. It is true that they were acknowledged as superior with regard to Truth (they were something like philosophical samizdat, to which the Party leadership paid almost no attention). The important thing was that the ideational-ideological ritual was observed...

Keti Chukrov: And can not it be that this explosion related to the economic traits and conditions specific to socialism? Many remark the importance of the economy of free, emancipated time under socialism, where there is a feeling of a "society of common ownership," where various sectors of time do not need to be privatized, where there is no private property (Vadim Mezhuyev, for example, has written a lot about this). At present, after all, there is also access to information, but our relationship to time and to knowledge has completely changed.

Valery Podoroga: Unquestionably, for such profound engagement with philosophy we needed time, and a lot of free time. But it was not the 
time of a free socialist society that had finally reached its maturity. On the contrary, it was the time of scarcity of freedoms and scarcity of basic human initiative, their suppression. In prison, particularly in solitary confinement, we possess the greatest possible amount of free time (unless, of course, we notice that we are in prison, and that we are deprived of many freedoms that people are endowed with from birth). Ironically, if there is an achievement of "actually existing" socialism, it in fact pertains to the time of its disintegration! Nothing binds you to great historical time, you are outside of it, together with the whole society, but on the other hand you have a lot of "minor" time that defines your evolution as a scholar and a human being. The friends of my youth and I made the fullest use of that.

Today, however, other generations, who were caught unawares by Perestroika, have not had that time, the "free time of the period of disintegration.” They have needed to simply survive, to keep moving, not read books, not sit in libraries and not discuss abstract and extravagant subjects, not collect household libraries... Of course, some are better off where free time is concerned, some are worse off, but it can no longer be found. But the main thing is we were living with just an inner feeling of freedom, and everything that was coming from the Outside (the environment, Party censorship, a shrill and empty ideology, pennilessness, the avalanche-like "deficit" in supply of basic everyday goods in the decades of late socialism) was rejected from the outset, was not interesting...

Keti Chukrov: Soviet cinema depicts locksmiths and plumbers who analyze the production process and calculate algorithms of an enterprise's economic growth. An important theme in cinema involves showing a worker as an agent who has a grasp of the whole production cycle in advance, and who can present his analysis to the Party leadership. The working class is shown to be something like the main analyst...

Valery Podoroga: Once, while I was still a first-year student, I took part in a big sociological study that was made at the Likhachev factory in Moscow; I went there every day and gathered the results of research interviews taken from a select group of workers. I was particularly struck by one instrument mechanic who for some reason was working on a conveyor belt. His task was fastening the wheels on the axis of what would become a truck. He was unable to answer any of the interviewer's questions, he just didn't understand what they wanted from him. For example, I asked him his sex and he thought about if for a bit but just couldn't bring himself to answer. He didn't know the word "sex" in that sense and didn't know the definition of "male." Today that might be excusable and understandable in gender terms, but at that time? So the ordinary worker was a long way from being the main analyst. But in fact in the eighties a lot of pre-Perestroika films came out in which we see such workers or engineers, new leaders of production, what were called "Red directors," but in the 
nineties all these illusions of a great "just" and "effective" Reform were smashed to smithereens. Of course, we had what was known as the higher proletarian layer, the "shock workers" closer to the regime (miners, dairy workers, mechanics and machinists, combine operators and weavers). They were the ones who were awarded orders, distinguished titles, pay raises and apartments. I repeat, in order to preserve the socialist utopia, it was necessary to maintain the absolute (not relative) poverty of the whole society. And poverty is a form of equality. Thus the energy of Nietzschean ressentiment is weakened...

Alexei Penezin: I would like to know whether there was some overlap of the processes of the late Soviet "information explosion" you describe, and the socio-ideological situation that you, and many others before you, have called "doublethink," with the very structure or "style" of the Soviet philosophical thought of that time?

Valery Podoroga: I will try to answer in more detail. But unfortunately, this subject clearly lies outside the limited framework of our conversation. For the professional formation of the entire generation of philosophers of the fifties and sixties, their relationship to Marx and Hegel played a defining role. For Merab Mamardashvili, the article "Analysis of Consciousness in the Works of Marx" (1986) was significant for the further development of the subject of this thought and of the whole domain of issues that he used to formulate his theory of consciousness. What does Mamardashvili show us and on what is he able to rely in his analysis?

First, however, a few points relating to how the material is presented. The principal device of the quasi-Marxist language of that time consisted precisely in finding in Marx's legacy what had become a locus communis with the modern Western philosophical tradition, but would be absolutely unacceptable to the orthodox ideological milieu of Marxism-Leninism. The name of Marx was used as a figure of speech that carried a double meaning-again, that same doublethink is at work here-with his name, a signal was sent out to two addressees: one signal to a narrow group of intellectuals, colleagues, and associates (to so-called "progressive society"), and the other to those in power, to those who directly oversaw $\mathrm{Vo}^{-}$ prosy filosofii and acted in the role of censor. That article is particularly revealing because in it the play of language, addressed to two different addressees, stands out with particular clarity-the "mature" Marx (the "working," preliminary manuscripts of Capital, at that time recently published, are selected from his body of work) is juxtaposed with the psychoanalysis of Sigmund Freud, but they are juxtaposed at the level of methodological orientations (though there are flickering chains of associations, half-concealed mutual connections between or among categories and concepts from the existential-phenomenological and structural planes, leading toward Husserl, Sartre, Lacan, and so on). The implication 
here is that Western (bourgeois) thought was only learning now to master what in Marxism had then been actively developing further over half a century. Mamardashvili is likewise "discovering" in Marx's ideas what purportedly has always been there. That was a widely used device, attributing to Marx everything that made him an opponent of any kind of Party orthodoxy and Marxist-Leninist ideology, and avoiding crossing over to the side of Marx the "Marxist," the ideologue of world revolution, the defender of the proletariat. Marx is improved by Freud, or even Althusser, joining the two of them in the right doses, but within the perspective of the latter's thought on the ideas of Jacques Lacan.

Alexei Penzin: I would like to clarify one point. Is this device of Mamardashvili for you only a more complex model of the matrix of "doublethink," which, according to you (and according to many liberal opponents and critics of Soviet society) dominated in the Soviet Union? Is not such an interpretation too sociological in its treatment of the philosopher's thought, which is, broadly speaking, autonomous and, as you yourself have said, "underground"?

Valery Podoroga: Fallacies in our work with conceptual (philosophical) language often prove a major obstacle to understanding what we are saying to each other. I mean to say that Mamardashvili saw this "doublethink" as a form that neutralized the ideological underpinnings of his own position. Although that doublethink was constantly under attack on the part of genuine Marxist-Leninists. " "Singlethink" was attacking, "doublethink" was the defence. We should not reduce the concept of "doublethink" to an unambiguous epithet and see it in a purely negative light. Nowadays there is nothing even remotely comparable to the doublethink that was simply a necessity in those years, in order to live, to survive. And more importantly, to be always ready to passively resist. Doublethink, of

3 The works of Evald Ilyenkov received official recognition, but that did not strengthen his position vis-a-vis the regime. Suslov, the main party ideologist, strongly disliked him. The story goes that there was even an episode where Ilyenkov was removed, on Suslov's orders, from the entry ramp to an airplane headed for a congress of Hegelians in East Berlin. Another example: I met Merab Mamardashvili in 1969, when he began teaching "Introduction to the Philosophy of Existentialism" to my year. After his return from Prague he had become the deputy to Ivan Frolov, editor-in-chief of Voprosy filosofii. I, then a graduate student at the Institute of Philosophy, would occasionally visit him in his office. He once told me he had been invited to a conference on the Frankfurt School that was to take place in Budapest. Knowing that I was working on that very topic, he asked me for my copies of Adorno's Negative Dialectics and the twovolume edition of Max Horkheimer's works. Some time later he gave me the books back, but with a sad look on his face. I distinctly remember what he said to me then: "So, now I'm restricted from travelling abroad.” They didn't let him go to the conference after all. It seems Suslov disliked many talented Soviet philosophers, including Merab. 
course, was not cynicism, it was not the nihilism of the ninteenth-century raznochintsy (literally, "people of miscellaneous ranks," nineteenth-century Russian intellectuals of non-aristocratic descent), it was an immune system developed through centuries of imperial and Stalinist serfdom within the social organism, a deformed and imperfect organism, but at the same time able to sustain itself with a great deal of diversification and effectiveness. Mamardashvili was not a virtuoso of Aesopic language, and nevertheless he made the fullest use of the institutional program that softened the ideological pressure from the CPSU on society's intellectual elite. Doublethink was transformed into the increased complexity and the "inviolability" of the intellectual product. ${ }^{4}$ The range of Western thinkers whose names or work were drawn into commentaries, partial translations, or summaries expanded considerably. The complexity and difficulty of Mamardashvili's thought was welcomed by young students and scholars, but was frowned upon by, for example, his colleagues.

Alexei Penzin: I have another, more general question. I will remind you that the term "doublethink" was introduced by George Orwell-an anti-authoritarian socialist in his views, let us note-in the novel 1984 (first published in 1948). Since that time, the societies of "actually existing socialism" have been depicted according to this canon that originated in literature: the reign of an alienated pseudo-rationalist Utopia that degrades individual freedom, spreads “doublethink," cynicism, indulges base desires, and so on. In anticommunist discourse, the masses who inhabit Soviet society, in contrast to the select few, consisting of the intelligentsia or "elites," who endure "doublethink" in torment, are depicted as unhesitantly accepting the bifurcation of existence into the "official" façade and the unsightly "actually existing" reality. They are refused the right to be free to think, to form their own independent relationship to Marxist doctrine. After Perestroika, the torrent of journalistic pronouncements on Soviet "doublethink" was simply colossal-here, I'm talking about the perceptual experience of my post-Soviet generation. These unmaskings-undoubtedly important for that period-formed the basis for the rise of a new official ideology that ascended the throne at the time of our intellectual and political formation. And insofar as we were also critically oriented toward dogma-but now facing this other, right-wing, liberal, anticommunist one-it could not fail to arouse suspicion, especially among those who had become interested in the tradition of leftist thought, beginning with those same authors we were discussing here (Lukács, Sar-

My first publication in the journal Voprosy filosofii (Problems of philosophy) was simply staggering for my father when he looked at the contents of that issue. It opened with a leading, guiding article by the Party ideologist at the time, Mikail Andreevich Suslov himself, and in the section "Philosophy Abroad," at the very bottom, there was my article on Adorno's negative philosophy. 
tre, Althusser, and others). Without question, your analysis is very different in character and is based on what you personally have witnessed as a critical intellectual and scholar. But all the same, are you not made uncomfortable by the proximity of the term "doublethink" to the basic lexicon of this new postcommunist (and anticommunist) ideology? And is there in fact any shortage of "doublethink" in the context of contemporary capitalist societies, including the contemporary postcommunist reality itself? Perhaps we ought not to exaggerate the value of this peculiar kind of socialist "doublethink" and should look for other languages and terms for the description of this historical experience? I assume that with regard to the questions that interests us in this conversation, the experience of "doublethink" figures only as a context of Soviet "Marxisms," and it's a whole separate theme.

Valery Podoroga: Actually, is there really any sense in breaking through an open door, when it's already open... What we call doublethink can also be defined in Kantian terms and called what, as everyone knows, he termed common sense. At that point we have expanded the concept of "doublethink" to such an extent that it loses all heuristic value. I would rather say that today there is no doublethink, no ideological cover for the values that have been lost, whether in the West or in the East. But after all, you and I study some of the conditions without which Soviet Marxism could not have taken shape. And one such condition for example, is the duality of the social individual that was directly expressed in the difference on which I continually insist: Marx against Marxism, Marxism against Marx. That is the rhythmic structure of Soviet "doublethink." You now are talking about another kind of doublethink, the doublethink of the authorities and the political regime, its functionaries, while I am talking about "doublethink" as a defensive mimetic form used by any person with common sense. You are talking about the doublethink imposed by the authorities, but that is a mistake. It is we, as highly virtuous beings, who judge our own Authority from the point of view of moral and ethical criteria that it seems in some sense to lack. In Andrei Tarkovsky's film The Mirror, there is an episode called "The Misprint"-a wonderful example of doublethink that could be "found out" by the authorities, the Party's inquisitors were just waiting for such a chance. For a "misprint" one could even go to jail. Such were the phantasms left over from Stalinism, which turned out to be a source of new creative projects. In "Soviet kitchens" people were discussing questions of deep hermeneutics in the recently published novel Live and Remember by Rasputin, all sorts of recent events and announcements-and everywhere people were searching for the "second bottom"-the real meaning was always being hidden by the authorities. The regime proposes its game, and we, all of those who were still able to take interest in something and react to something, propose ours, a mirror reflection, you-this way, we-that way. In reality, the rule of the political 
regime at that time had been deprived of this "doublethink" and had no need of criterial assessment, it acted crudely and stubbornly; what's a different matter is that changes were already taking place there too, slowly, but they were happening. And the main thing in those changes was the weakening of ideological control over the population and society. It became less and less effective without the use of force, and therefore the collapse of the ideational-ideological sovereignty of many government apparatuses, including the Central Committee of the CPSU, began.

\section{Metamorphoses of the Ideal}

Alexei Penzin: All the more interesting, given the atmosphere in the late Soviet society you describe, is the philosophical discussion of themes that at least on the surface level contradict that atmosphere, above all, the famous discussion about the "ideal," one of whose main protagonists was Evald Ilyenkov. When reading Ilyenkov, one marvels at his crystal clear style, which varies in tone from strictly academic to popular-scholarly and "activist," one grasps his superb knowledge of the history of philosophy, of Marx's texts, and so on. But sometimes he seems to be reproducing with greater depth, in its most polished and intellectually refined form, a certain collective Soviet philosophical discourse, the theory of labor and activity, above all. Was there something unique in Ilyenkov's Marxism? Lifshitz, for example, criticized Ilyenkov in connection with the fact that in developing his conception of the social "ideal," he undervalued the nuances of Marx's German terms - "Ideale" (ideal as in perfected) and "Ideelle" (the term emphasises ideal as the opposite of material). But it seems that due to these terminological complexities, Ilyenkov managed to make some interesting discoveries in his development of the concept of the "ideal."

Keti Chukrov: Very often, Ilyenkov, and even more so Lifshitz, are accused of being in essence more concerned with Hegel than with Marx. After all, they rehabilitate such concepts of classical philosophy as "truth," "objective reality," "the universal," "the ideal"-that is to say, those concepts that posit a monism, even if it is dialectical, where the dialectic becomes an instrument of maintaining this unity; whereas Western philosophy is either constructed on a dualism of thought and being, or resolves the question of the classification of matter by refusing such categories as the idea, the ideal, the universal and so on. The unity of thought and being and the belief in de-alienated spheres of social being in conditions of historical socialism are the reasons why Althusserian Marxism does not trust socialism as a structure. To assert that alienation can be removed in the ideological struggle for unity, in the context of "Western" Althusserian Marxism, is considered idealism. How do we deal with this? Althusser, as 
we know, held that historical socialism was, if anything, a palliative to capitalism, and that it was closer to capitalism than to communism. Whereas communism becomes established, not as a structure, but as a process of critique and communization. And for that reason the critical process in the conditions of capitalism answers to the tasks of communism more than an actually existing socialist society. That means that Soviet socialism as well as Soviet Marxism can be ignored, since it does not perform the work of communization either in theory or in practice. ${ }^{5}$

Valery Podoroga: You have raised some truly important questions. Without answering them, it is not possible to understand the role that the concept of the ideal played in the development of the Soviet version of Marxism. ${ }^{6}$ The first thing that needs to be immediately noted is that there is a single, common approach taken by all of the most influential Soviet Marxists, beginning with Ilyenkov and Zinoviev and continuing up to Shchedrovitsky, Mamardashvili and Lifshitz. This approach was often called the activity approach (deiatel'nostnyi podkhod) or the materialist worldview. And the legitimacy of its use gained a foothold in all discussions about the ideal, and especially where there was a more comprehensive survey of the theme of consciousness and knowledge.

For example, for Merab Mamardashvili, this role was played by the theory of "converted forms," but it was already an attempt to "sublate" subjective, activity-related forms of knowledge. To go outside the boundaries of Marxist propedeutics toward the systemic-structural Marx, and then beyond him toward Marx as a phenomenologist of consciousness. There was no longer a need for the tacitly assumed Subject of activity, and after all that is precisely the possessor of the "ideal," that primordial form, necessary to construct the world and the self within it. Here we see a beautiful form of double construction: we construct the world, while it constructs us, and to the extent that this takes place simultaneously, the world is given a boost towards development. The Marxist subject suffers from not having enough of the "ideal" to grasp the universal, that is, to inscribe Nature, Society, and Consciousness in one horizon. He compensates for this lack by what we call the dialectic, which no longer inspires trust as a universal method. And nowadays, in my view, it is perceived in the old Platonic rhetorical forms, or negatively. ${ }^{7}$

\footnotetext{
See Balibar (2015).

Consider: "Let us note incidentally," Ilyenkov writes, "that in translations of Hegel's works the adjective ideelle, meaning 'ideal,' is rendered as 'idealized,' in order to distinguish its meaning from Ideal, relating to the problem of the ideal, which, for Hegel, functions as a problem of aesthetics" (Ilyenkov 1962: 222).

Adorno's "application" of this principle is outstanding. He created the theory of "negative dialectics" or the philosophy of disintegration, in which dialectics as a method can only be negative or cannot exist at all, there can be no syntheses or congru-
} 
Alexei Penzin: Your reading of the "ideal" as a kind of symptom of the lack from which the Marxist subject suffers is very interesting, one would like to learn more about it. But I don't fully understand what you mean when you speak of this lack being compensated for by the dialectic, which allows the inscription of all spheres of being into a certain totality. After all, after Adorno there were some further shifts in the conceptualization of that theme. For example, the dialectic may be not only negative, and not founded on totalization, but can be conceptualized as an inherent paradox, a logical anomaly, expressing the social antagonism which cannot be neutralized through simple "sublation"... On the other hand, that same Ilyenkov, in his later work "Dialektika ideal'nogo" (Dialectics of the ideal) (2009), it appears, understands dialectics not as a form of totalization, eliminating differences, but rather as logic and way for the ideal to exist in activity-in a constant metamorphosis of de-objectification (sublation), objectification (positing), and so on.

Keti Chukrov: I would add, nevertheless, that despite of the activity approach to dialectics, for Ilyenkov teleology and projectivity remain the central focus of his interpretation of the ideal. His understanding of the dialectic is entirely holistic, for the simple reason that any process of labor is, for him, teleological. The difference between Ilyenkov's and Lifshitz's interpretations of the ideal was that Ilyenkov understood the ideal as a diachronically viewed social and labor process which, as it forms social consciousness, reveals itself through human consciousness as well. Lifshitz, on the other hand, considered the ideal to be the form itself of "objective reality," which is possible even without the intervention of the Subject, without the participation even of social, much less individual consciousness. So that for Lifshitz, the ideal is possible outside of consciousness, while for Ilyenkov it is not, though for him, consciousness is also itself a reflection of the diachronic, historical progression of society and labor.

Valery Podoroga: Wherein lies the secret of the translatability of these two terms, Ideelle and Ideal, to which Ilyenkov, and, later, Lifshitz, draw our attention? In fact, Lifshitz's position seems ambiguous, like almost everything he wrote. Being excessively dialectical, he is quicker to look for contradictions and inconsistencies than to propose a way out or a final alternative formulation of the problem. I think this is part of his strategy as a Marxist critic: to shake things up, to "mess up the party" in the words of Daniil Kharms, but not to correct or to conceal. In Russian philosophical jargon the definition of idealnoe ("ideal," adj.) solidified

encies, nothing universal; then the dialectic in in its negative status is seized by the energy of disintegration, and precisely in that sense it is, in Hegelian terms, real (real as disintegration, not as construction). 
quite a long time ago, as did ideal ("ideal," n.), and the German word that should be translated as idealizovannoe ("idealized"), coincides with the unfinished nature of the process, its non-transient state, what are called "third things," or sensory-super sensory phenomena, and is a direct condition of the functioning of consciousness. It is one thing when consciousness is focused around a certain goal and the conditions for attaining it, it acquires subjecthood, even becomes a Subject-in-action, and something else again when consciousness functions in its quality of consciousness, without the ideal, that is, at the level of the vulgarly ordinary and natural limitations of everyday experience, outside of self-reflection and critical self-evaluation.

Really, where you are right is in saying that the theory of reflection (according to Pavlov/Lenin/Lifshitz) is a universal ontology of the all-reflecting nature of matter, all things in everything, the one in the many, the many in the one, and so on. In M. A. Lifshitz we find a very extensive commentary on the concept of the ideal. And this is far from random. Above all, Lifshitz wanted to return to the modern philosophical polemic, and a second thing, no less important: to clarify his views on the Marxist theory of reflection through comparing it with Ilyenkov's theory of consciousness (Lifshitz 2003). His understanding of the ideal has a fixed analogy, which he persistently uses, not attempting a more critical conceptualization of it-and that is the mirror. The metaphor of the mirror is used in several conceptual tasks: first as an explanation of the theory of reflection: the world is objectified by means of its being reflected in itself, by means of its own mirror-like, mirroring aspect. Further on, the mirror is shown to be what may be called an ideal reflection, that is, it reflects within itself the world and other mirrors, such as they are in reality:

In order to acquire a consciousness corresponding to his nature as a conscious being, the human being needs an object that can serve him as a mirror of a certain group of phenomena, the bearer of their universal meaning. This thought is true, and it contains within it the only possible serious understanding of the theory of reflection in Marx and Lenin's system of materialist philosophy. The theory of reflection is, in fact, a theory of the reflectivity of the most objective phenomena, their mirroring capability (Lifshitz 2003: 262).

We can understand why the ideal, as it is presented in Ilyenkov's and Mamardashvili's studies of Hegel, is so in need of consciousness-in order to free itself from matter, and go outward toward the animate Subject (of action). For Lifshitz, as a Marxist critic of aesthetics, the theory of reflection also functions as the basis of a naturalistic ("Socialist Realist") approach to the work of art.

If we consider Hegel in the period in which he wrote Phenomenology of Spirit (1977) we note that he had already formulated the main idea of 


\section{Marx Against Marxism, Marxism Against Marx}

the dialectics of the ideal (consciousness) at that time. We are always inside consciousness, and cannot exit precisely because it is real, in its being, it is what is real itself. Moreoever, this dialectic is not simply a method, but the very principle of development, which extends to nature as well-this is why the Hegelian dialectic is real.

But what does real mean here? It means that consciousness for Hegel is real because it speaks. Consciousness is human speech, constantly unfolding. This speech finds itself in continual gyration, moving forward, turning back, in other words it is language-in-action, in the act of selfrealization. Ilyenkov was deeply familiar with this defining role of language in Phenomenology of Spirit (but for example, none of the most influential interpreters of Marx posed this question about language, or they simply ignored it) (Ilyenkov 1962: 222). After all, Hegelian language/ speech is a specific philosophical language, it is given in movement, which means that it must possess a kind of spontaneity that cannot be distorted by any phenomenon. In other words, the power of expression of this movement in language is great to the extent that nothing can disturb it, no expressible content. The total prevalence of expression over what is expressed. And this is responsible for its uniqueness, the uncommon, distinctive character of Hegel's work, with all of its transitional moments in a concept that develops without stopping or pausing, perhaps only delaying slightly before shifting to another level of self-reflection and intensifying its movement. Concept-in-movement is the time of speech, which must not be interrupted or the world will perish...

Modern Western thought (most often in manifestations of the Anglo-Saxon philosophical tradition) accepts existence, void of consciousness, consciousness without human beings, that is, essentially inhuman (machinic, for example). It can be filled in, structured, changed, studied, and it will always remain open and defenseless in the face of such encroachment. Mamardashvili, on the contrary, without discussing the role of language in the Hegelian dialectic, or examining the question of consciousness as continuity of speech flux or becoming, notwithstanding defines the self-consciousness of every kind of thinking being in utterly Hegelian terms, positing that authentic philosophizing is "consciousness out loud," that is, a speaking consciousness, not a silent one.

Very few have noticed (and it has never been discussed) that at the foundation of the doctrine of the "improved" or "good" Marx there lies a certain anthropological tenet-the indestructible, ineffaceable stamp of an early Enlightenment archaism - that is the figure of the Eternal Man (and the human). And that means that we are dealing, even in the most advanced Marxism, with variations on a position of a dynamic, that is, an extremely active Subject. And without it, as it turned out, Marxism, even in its renewed "post-" variations is still unable to exist either as a doctrine, an ideology, or, in the end, as an Idea. There is an assumption-you only need to be attentive in your reading-that the human being is what it is, 
and that its evolutionary form need not be discussed, it is given in our reasoning from the beginning, as the Subject, whose new characteristics we are to receive. But to put in doubt the existence of Eternal Man is just madness and explicit, wild "Postmodernism." Many French intellectuals can be accused of belief in this Eternal Man, although they deny it in their works and interviews. And this belief in Man is there along with the deconstruction of the image of the Sovereign, the Father, the Subject with a capital $S$ that rules in mass consciousness, is an unending process. From there we get the theory of the Subject-multitude, in place of a certain solitary Marxist Subject, omnipotent and single-minded, the communitymultitude arrives, where subjectivity is not shrunken into a single, albeit ideal focus of action, but is divided into the horizontal interactions of those who exist con-jointly, concomitantly, synchronically (Bataille, Derrida, Nancy)

Alexei Penzin: To the extent that I understand your argument in its entirety, you believe that Soviet thought inherited from Hegel the model of a "speaking consciousness," with its inherent anthropologism, which it was unable to get rid of. This argument, certainly, demands further discussion, that is, in the context of different interpretations of Hegel-from Kojève's, it seems to me, very similar interpretation to contemporary "Lacanian-Hegelian" approaches (Kojève 1980). However, we can hardly get into those within the limits of this dialogue. But still, what do you think, were there in Soviet Marxism (or Marxisms) moments that might indicate a different logic than this "anthropological slumber" that has been criticized since the 1960s by Foucault, Althusser, and others? For example, Lifshitz himself-at least, in his work on aesthetics-comes out with a furious critique of bourgeois-individualist "subjectivism," which distorts the "mirror" of our perception of the world, seeming to point to another way... I would also like to understand what other program (both theoretical and political) you see, with relation to the highly unsuccessful-as what you have said implies-searches of late Soviet Marxism, which to some extent have been continued in contemporary radical leftist thought?

Valery Podoroga: Your reference to an "alternative," insofar as I understand it, can be translated into the question: And what is your Utopia, what is your philosophy hope, what do you believe in or not believe in? I hold, and have always held, to a moderate position and it has, it seems to me, been laid down fairly clearly in the foreword to my Apology of the Political (Podoroga 2010). You pose the question as if it were both "standard" and, of course, "beyond all suspicion," and it is truly a question addressed to your belief. You doubt that such belief exists, but you need it. Where is the boundary that allows us to move from Belief to Action? Well, there is none! Where there is Action, there is no Belief. I call my action, which I 
practice, the politics of knowledge, that is, the kind of knowledge, which within its own, no doubt limited, horizon, introduces a new vision into the world. And this knowledge is critical, insofar as it is undeniably superior to the pseudo-knowledge of the demagogues and court jesters in the media, the presenters and political functionaries. Here Knowledge has a correlation with Truth, which strengthens our "faith" in Reason. But it is, of course, not just Faith and not "pure faith," but a faith that brings itself into being by means of Truth, that is, acquired knowledge. The politics of this knowledge lies in the fact that it cannot be called into question by a larger Politics (meaning that it does not result from the struggle for power), its goal is Truth.

I am confident that we cannot nowadays discuss Marxism in the way that Ilyenkov and Lifshitz did, Merab Mamardashvili or Althusser, as if to continue their "Marxist discourse" in the contemporary, postmodern era. At the same time, I will note that they did not reveal their context due to considerations of censorship as well as simply because it was always obvious, "right before our eyes," in the form of the everyday facticity of a society in "mature socialism."

The problem is that the whole problematic of Marxism should be discussed from below, not from above, as the "men of the sixties" discussed it. For that reason, when you say left-leftist, right-wing, neoliberal, or class, alienation, totality, totalization, and so on, you seemingly know what those things are but I can have doubts precisely about such knowledge, not supported by experience and context. You are using the old names all over again, but you don't indicate the reasons that would justify such a use of Marxist language. You seem to be already at the top, when in reality there is no eternal Marxism to which we can refer as if it were something known to everyone and cherished by everyone! I mean that Marxist terminology (as it is used today) throws into confusion the previously existing Marxist discourse. Inasmuch as it employs it too freely and in a headstrong manner, you might say “in the dark.” Today we don't have the Marxism that was so obvious in its premises and examples even in the "prosperous" times of the 1960s. But even then the knowledge of Marxism was being newly "reworked," so as to reconcile the previous content of Marxist terms and concepts with new contexts and challenges. That was what led to all the trends of late Marxism, or more aptly, post-Marxism, its attempts to return to the Hegelian dialectic, but this time from the position of $\mathrm{Ki}$ erkegaard or Heidegger, or from the position of structuralist or poststructuralist theory, for example.

What does it mean to be a Marxist today? This talk is in some sense under the spell of that question, but can't find the answer. In my own understanding of being a Marxist in these times, it doesn't mean being a leftist (I do not think that leftism is a sign of adherence to Marxist teachings). I in no way deny "your convictions," nor do I aspire to change them. I will remind you of Lifshitz and his manifesto "Why Am I Not a Modernist?” 
and Andrei Bely's text-testament "Why I Remain a Symbolist...” published after his death (1982). And, finally, the apocryphal Karl Marx statement, “Why Am I Not a Marxist?" Marxism today has probably been given many advantages compared to the fate of the Hegel-Marx-Kojève-Adorno school of thought, you might say that Marxism has conquered not as a new Utopia of the future but rather as the most comfortable form of temporary deliverance from the pain and discomfort of the present. The new and rather "glamorous" Marxism is anti-revolutionary, bourgeois through and through, that is, it has no relation to the Marxism of either Lukács or Lifshitz. My sense is that if Marxism were even possible, it would be as a kind of aesthetic doctrine... But even that adventure is one Marxism has already been through... But would we feel "equal" if we were to be told that now everyone will again be poor, that there are not and will no longer be any rich people, did that mean that it was a just society?

Alexei Penzin: I will perhaps permit myself a final comment. I did not, of course, have in mind a dogmatic "faith," blindly copying the old terminology. What we are talking about is precisely how there can be a return to Marx under new conditions, where we are confronted rather with the ideological dogma of anticommunism, together with those same "contradictions" of capitalism, which after the Soviet collapse returned with unprecedented and ominous, catastrophic force-in a world that, to all appearances, was supposed to be subordinate only to a kind of "post-historical" politics of knowledge and critical rationality. And this turn toward philosophies connected with the name of Marx affected not only a part of the post-Soviet generation, but in fact has been a completely international phenomenon since the early years of the twentyfirst century. You have done a beautiful job of explaining the reasons for your doubts as to whether we can use the "old" language and conceptual apparatus of Marxism or "Marxisms," both from the point of view of a witness who came of age thrown into the "facticity" of Soviet experience and, naturally, from the point of view of your own political and philosophical experience, reflected in your many outstanding works. Yet all the same, I would like to note that the generation who have begun once again to employ Marxist language-whether the post-Soviet generation here or their counterparts in the wider world-is involved in a fairly complex process of reflection regarding the conditions governing the possibility of using those terms. As I am unable here to develop this thesis in detail, I will merely refer you to one particular point. So, in my view, this reflection expressed itself not in a "faith" that grew out of subjective recalcitrance, but in an utterly distinct relationship to the inner temporality of the enormous history of radical thought and practice in the twentieth century-both Soviet and "Western." The past was not imagined as a completely closed or "dead" archive, open to exhaustive analysis but in no way to being updated. Such a historicism, in its way abso- 


\section{Marx Against Marxism, Marxism Against Marx}

lute, was rather rejected, and other forms of relations to history, both philosophical and political, were sought out. This represents a certain kind of anti-historicism, and perhaps it is no less productive: only in a different period can the intellectual and political experience of the past-even if it was given in the forms of completely unglamorous Soviet "facticity" or its "doublethink"-be "redeemed" (as Benjamin would say), read anew and fulfilled. And Soviet thought, having historically been subjected to a double expulsion-both from inner Party dogma and from "Western Marxism"-only now, after being freed from this "double bind," has a chance of becoming truly meaningful and radical.

Moscow, Institute of Philosophy of Russian Academy of Sciences, March $2016^{8}$

\section{Bibliography}

Balibar, Étienne (2015). “Althusser and Communism.” Crisis \& Critique 2.2: 9-23.

Bely, Andrei (1982) Pochemu ia stal simvolistom i pochemu ia ne perestal im byt' vo vsekh fazakh moego ideinogo $i$ khudozhestvennogo razvitiia [Why I became a symbolist and why I remained a symbolist in all stages of my intellectual and artistic development]. New York: Ardis.

Grushin, B.A. (1961). Ocherki logiki istoricheskogo ussledovaniia. [Essays on the logic of historical inquiry] Moscow: Vysshaya shkola.

Hegel, G. W. F. (1977). Phenomenology of Spirit. Trans. A. V. Miller. Oxford: Oxford University Press.

Ilyenkov, Evald Vasilevich (1962). “Ideal'noe.” [The ideal]. In Filosofskaia entsiklopedia [Encyclopaedia of philosophy] Vol 2, 195-99. Moscow: Sovetskaya entsiklopediia.

Ilyenkov, Evald Vasilevich (2009). “Dialektika ideal'nogo” [Dialectics of the ideal]. Logos 1.69: 6-62.

Khromchenko, Matvei (2004). Dialekticheskiie stankovisty. [Dialectical “Easelists”] Moscow: Shkola kul'turnoi politiki.

Kojève, Alexander (1980). Introduction to the Reading of Hegel. Lectures on Phenomenology of Spirit. Cornell: Cornell University Press.

Lifshitz, Mikhail (2003). Dialog s Eval'dom Il'enkovym. Problemy ideal'nogo. [A dialogue with Evald Ilyenkov. Problem of the ideal] Moscow: Progress-Traditsiia.

Lukács, Georg (1971). History and Class Consciousness. Studies in Marxist Dialectics, trans. Rodney Livingstone, Cambridge: MIT Press.

Mamardashvili, Merab (1968). Formy i soderzhanie myshleniia. K kritke gegelevskogo ucheniia o formakh poznaniia. [The forms and the content of thought. Towards a critique of Hegel's doctrine of forms of cognition] Moscow: Vysshaya shkola.

$8 \quad$ The participants in the conversation wish to express their gratitude to Marysa Prorokova, graduate student in the Department of Analytic Anthropology, for transcribing the audio recording of the talk that became the first draft of this text. 
Mamardashvili, Merab (1986). "Analysis of Consciousness in the Works of Marx.” Studies in Soviet Thought 32: 101- 20.

Mamardashvili, Merab (2016). Vstrecha: Merab Mamardashvili-Lui Alt'iusser. [The Encounter. Correspondence between Merab Mamardashvili and Louis Althusser] Moscow: Fond Meraba Mamardashvili.

Podoroga, Valery (2010). Apologiia politicheskogo [Apology of the political]. Moscow: Vysshaya shkola.

Podoroga, Valery (2016). "Mikhail Lifshitz: Orthodox Marxism Versus Modern Art," a public Lecture at the Garage Museum, www.youtube.com/watch?v=zXtqtMU2vgI

Shchedrovitsky, G.P. (2004). Na doskakh. Publichnye lektsii po filosofii [On the boards. Public lectures in philosophy] Moscow: Shkola kul'turnoi politiki.

Zinoviev, Aleksander A. (2002). Voskhozhdeniie ot abstraktnogo k konkretnomy (na materiale «Kapitala» Marksa). [Ascending from the abstract to the concrete (A reading of Marx's Capital)]. Moscow: IF RAN. 